\begin{tabular}{ll}
\hline 論 & 説 \\
\hline
\end{tabular}

耳鼻咽喉科外来の消毒・滅菌

\author{
重 野 浩一郎
}

\title{
Disinfection and Sterilization in the Otolaryngologic Outpatient Clinic
}

\author{
Kohichiro Shigeno \\ (Shigeno Otolaryngology Vertigo-Hearing Impairment Clinic)
}

\begin{abstract}
For the disinfection and sterilization of otolaryngologic instruments in outpatient clinics, two processes exist. One process is used for heat-resistant instruments: cleaning $\rightarrow$ physical disinfection $\rightarrow$ drying $\rightarrow$ (autoclave sterilization), while the other process is used for non heat-resistant instruments: cleaning $\rightarrow$ chemical disinfection $\rightarrow$ rinsing $\rightarrow$ drying. In both processes, cleaning is especially important. For metallic instruments, disinfection by boiling or hot water disinfection combined with autoclaving for sterilization provides safe and economical disinfection. Instruments such as the nebulizer can be soaked in sodium hypochlorite, dried, then used. Especially important in the case of the nebulizer is clean management of the inhalant liquid. In disinfection of the flexible endoscope, the use of an automated cleaning machine has spread. Using Ortho-phthalaldehyde, disinfection with a short immersion time (five minutes) is possible. Finally, to prevent nosocomial infection, it is critical that all medical staff wash their hands properly.
\end{abstract}

Key words : disinfection, sterilization, otolaryngology, outpatient clinic

\section{はじめに}

SARS, 鳥インフルエンザ, HIV などの感染症やMRSA による院内感染は, 日々マスコミで取りあげられている. 一方，行政に㧍いては感染症法の改正が行われ，平成 15 年 11 月より施行されている. 感染症法では, 従来の集団 の感染症予防に重点を置いた考方方から個々の国民の予 防，さらに社会全体の感染症の予防や推進に基本的な考 え方の転換が図られている，このような状況のなか，感 染症に対して第一線となる診療所, 特に耳鼻咽喉科外来 での消毒や滅菌はどうあるべきなのだろうか?

基本的な消毒と滅菌の概念については,「消毒と滅菌の ガイドライン」1）を中心に解説し，具体的な耳鼻咽喉科 外来の消毒や滅菌の有効性や適用について考察する.

\section{消毒と滅菌の概念および基本的な消毒・滅菌法}

\section{1. 感染制御について 11}

感染制御は感染症の発生と拡大を防ぐことである，感 染症の発生には，(1)原因微生物の存在，(2)生体の感受性 部位の存在，(3)感染症を惹起するのに十分な接種量と(4) 感染経路の成立のすべてが必要条件とされている，感染 制御とはこれらのうちの一つ以上を欠けさせる対策を意 味する．滅菌とはすべての微生物を殺滅あるいは除去す る処理方法である (1))。一方, 消毒は対象とする微生物 を，感染症を惹起しえない水準まで殺滅あるいは減少さ せる処理方法であり，一定の抗菌スペクトルを持った処 理方法である (3). したがって，すべての微生物に有効 な消毒法はなく, 必ず効果の及ばない微生物が存在して いる. 
2. 滅菌と消毒の種類と効果 11

耳鼻咽喉科外来で行われる滅菌には加熱法とガス法が あり, 前者では高圧蒸気法, 後者では酸化エチレンガス 法が一般的に行われている.

高圧蒸気法は熱に安定なものがすべて対象となり, 高 圧蒸気滅菌装置（オートクレイブ）の容器の $60 \sim 70 \%$ を目安にものを入れ滅菌を行う. 適当な温度と圧力の飽 和水蒸気を加熱することで微生物を滅菌する．液体であ れば $115^{\circ} \mathrm{C} 50$ 分，ゴム製品では $115^{\circ} \mathrm{C} 30$ 分，布類（リ ネン）は $121^{\circ} \mathrm{C} 20$ 分さらに鋼製品は $135^{\circ} \mathrm{C} 3$ 分で滅菌が 行われている．滅菌の確認のためにボウィーディック （Bowie Dick）式試験が薦められている.酸化エチレンガ ス法は加熱できないものが対象となる. しかし，ガスの 毒性や爆発性の問題，コス卜高，滅菌に時間かかる（ガ スを排除するエアレーションに $8 \sim 12$ 時間)などの欠点 があり，一般診療所では使いにくい。

一方，耳鼻咽喉科外来で行われる消毒には物理的消毒 法と化学的消毒法があり，前者では惹沸法と熱水消毒， 後者では各種消毒薬が用いられる. 図 1 は微生物の抵抗 性と各消毒法の有効性を示している.

煮沸法は現在でも耳鼻咽喉科外来の主要な消毒法であ る. 煮沸消毒器の沸騰水中に沈めて 15 分以上煮沸する方 法である，栄養型細菌，結核菌，真菌やウイルスを殺滅 できるが，芽胞（バシラス属やクロストリジウム属の細
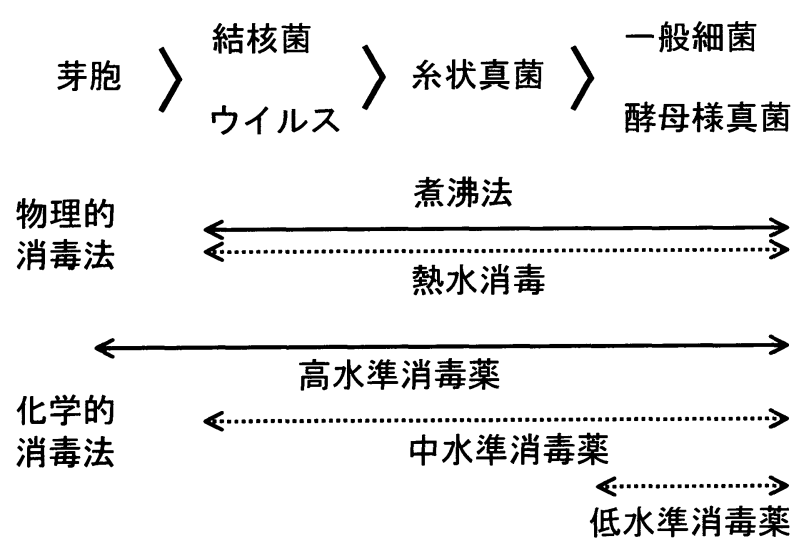

図 1 微生物の抵抗性と代表的な消毒法の有効性（消毒と滅菌 のガイドライン：へるす出版，20041) を改変）

煮沸法や高水準消毒薬は芽胞以外の微生物を殺滅 (一) で きる. 熱水消毒と中水準消毒薬は芽胞以外の微生物を感 染可能な水準以下に殺滅あるいは減少 $(\cdots)$ できる，低 水準消毒薬は一般細菌（MRSA を含む）に殺菌効果 $(\cdots)$ を示す。
菌）は滅菌できない，熱水消毒は $80^{\circ} \mathrm{C} \sim 93^{\circ} \mathrm{C}$ の熱水で $3 \sim 10$ 分間処理する方法であり（リネンは $80^{\circ} \mathrm{C} 10$ 分, 鋼製品は $93^{\circ} \mathrm{C} 10$ 分), 芽胞を除く一般細菌, 結核菌, 真 菌やウイルスを感染可能な水準以下に殺滅あるいは減少 することができる．いずれの方法も消毒の有効期間は消 毒当日に限られる．近年，洗浄・熱水消毒の工程が自動 的に行えるウォッシャーディスインフェクターが開発さ れている。

化学的消毒は熱が使用できない場合すなわち生体，環 境や非耐熱性の器具が対象となる.消毒の水準2)3）によっ て消毒薬は分類され，高水準消毒薬は大量の芽胞を除い たすべての微生物を殺滅できる，中水準消毒薬は芽胞以 外のすべての微生物を殺滅あるいは不活化できる，低水 準消毒薬はほとんどの細菌や一部のウイルスには有効で あるが芽胞，結核菌，ウイルスや真菌には無効である. 表 1 亿代表的な消毒薬の一般名（器具の消毒時の使用濃 度)，商品名（代表）を示し，特に金属や非金属への適用 の可否について記載した。高水準消毒薬はその毒性から 環境には用いられない，過酢酸は金属製品には不適であ る. 中水準消毒薬に属する次亜塩素酸ナトリウムは有毒 ガスの発生のため金属器具には用いられないが，低残留 性に特徴があり口にするような器具の消毒に適してい る.一般的に，消毒薬は以下のような項目について正し く調製し使用しないと無効であり，作業者に危険が及ぶ. (1)定められた希釈濃度（精製水や緩衝液による希釈），(2) 十分な接触時間 (一般的には浸漬), (3) $20^{\circ} \mathrm{C}$ 以上の温度, (4)有機物の除去を目的とした前洗浄，(5)毒性対策（ゴム 手袋やエプロン).

3. 基本的な消毒法の選択 ${ }^{1)}$

医療従事者の消毒は，院内感染の予防としてきわめて 重要である. 手洗いにより，手指を介した接触感染を予 防できる．目に見える污染は石畭と流水によりほとんど 除去できる．目に見えない污染の消毒には速乾燥手指消 毒薬による手洗いが行われている.

耳鼻咽喉科外来器具への消毒法の選択は感染症あるい は予測される感染症の種類によって決められるのではな く, 器具の使用用途に応じて決められる. 器具は, 無菌 の組織や血管に挿入するクリティカル器具，粘膜または 健常でない皮膚に接触するセミクリティカル器具と健 常な皮膚に接触するノンクリティカル器具に分類され $ろ^{2)}$.この器具の分類に沿って, 必要な消毒水準が示さ れている. 
表 1 代表的な消毒薬の分類と特徴

\begin{tabular}{|c|c|c|c|c|}
\hline 消毒薬 & 一般名（使用濃度） & 商品名 & 金属 & 非金属 \\
\hline \multicolumn{5}{|l|}{ 高水準消毒薬 } \\
\hline アルデヒド製荗 & グルタラール $(0.5,2 \mathrm{~W} / \mathrm{v} \%)$ & ステリハイド® & 0 & 0 \\
\hline アルデヒド製剤 & フタラール $(0.55 \mathrm{~W} / \mathrm{V} \%)$ & ディスオーパ® & 0 & 0 \\
\hline 過酸化物製剤 & 過酶酸（0.3W/V\%） & アセサイド & $x$ & $\triangle$ \\
\hline \multicolumn{5}{|l|}{ 中水準消毒薬 } \\
\hline 塩素酸塩製剤 & 次亚塩素酸ナトリウム（0.02～0.05 W/ $/ \% ）$ & ミルトン ${ }^{\circledR}$ & $\times$ & 0 \\
\hline アルコール製㶡 & エタノール（80 V/V\%） & & O & 0 \\
\hline \multicolumn{5}{|l|}{ 低水準消毒薬 } \\
\hline 第 4 級アンモニウム塩 & 塩化ベンゼトニウム（0.1W/V\%） & ハイアミン & O & O \\
\hline クロルヘキシジン製剤 & グルコン酸クロルヘキシジン（0.1〜0.5 W/V\%） & ヒビテン® & 0 & 0 \\
\hline 両性界面活性剂 & アルキルポリアミノエチルグリシン（0.05〜0.2 W/V\%） & テゴー® & O & 0 \\
\hline
\end{tabular}

代表的な高, 中, 低水準消毒薬の一般名, 器具の消毒に用いる濃度, 代表的名商品名, 金属と非金属への適用の可否について記載した.

クリティカル器具には滅菌，セミクリティカル器具に は高水準以上の消毒が必要である ${ }^{4)}$. 大部分の耳鼻咽喉 科外来器具はセミクリティカル器具かクリティカル器具 であるため，高水準以上の消毒が必要となる。ノンクリ ティカル器具は一般的には消毒の対象にはならない。し か乙接触感染の予防が必要な場合 (MRSA など)，ウイ ルスを除き，低水準消毒で対処できる11)。

\section{耳鼻咽喉科外来の消毒と滅菌の実際}

1. 医療スタッフの消毒と器具の準備や使用方法 耳鼻咽喉科外来で扱う器具類は多く，乙かも耳漏など 感染症を扱ら機会が多いため，医療スタッフの手指に病 原体が付着する可能性が高い。医療スタッフに付着した 病原体は容易に伝搬されらる。したがって，外来で扱う 器具の消毒や滅菌孝適切に行らと同時に, 医師, 看護師, 看護助手の寸べての医療スタッフが適宜手洗いを実行 し，病原体の伝搬を防ぐ必要がある6).

さらに, 耳鼻咽喉科外来器具の準備や使用方法を工夫 することも大切である。例えば，器具の準備に際し，ス タッフは滅菌したゴム手袋をつけて器具を並べたり，容 器に器具を立てていく (図 2). 鑷子類, 吸引管, 喉頭鏡 や上咽頭鏡, 通気管, 舌圧子, 鼻鏡や綿棒などの患者に 接する先端部分には医療スタッフの指が触れないように 配置する。 また, 医師もこれらの器具を手にする際には, 患者に接する部分に注触れないように注意する。そのた め, 滅菌した容器に鑷子, 吸引管や通気管の先端, 喉頭 鏡や上咽頭鏡の鏡の部分, 綿棒の先を下にして立てる(図
3）。その他，左右耳で異なった耳鏡を使用する。架台に かぶせられている耳鏡を取る際，他の耳鏡に指が触れな いように注意するなどである。

2. 耳鼻咽喉科外来器具の消毒と滅菌

前述したように, 大部分の耳鼻咽喉科外来器具はクリ ティカル器具かセミクリティカル器具である. 手術器具 はクリティカル器具に属する。 その他の検查器具や処置 器具はほとんどセミクリティカル器具に属している。多 くの診療所では, 1日数回繰り返しこれらの器具を使用す るが，綿棒などはディスポーザブルなものを用いること ができる。

クリティカル器具やセミクリティカル器具は金属製と 非金属製に分けられる。金属製は鑷子類，耳鏡，鼻鏡，

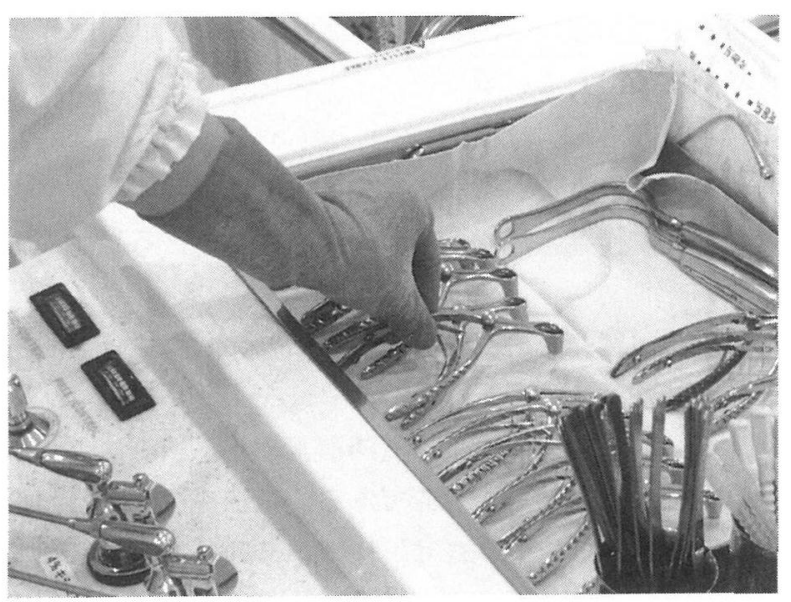

図 2 医療スタッフによる器具の準備 


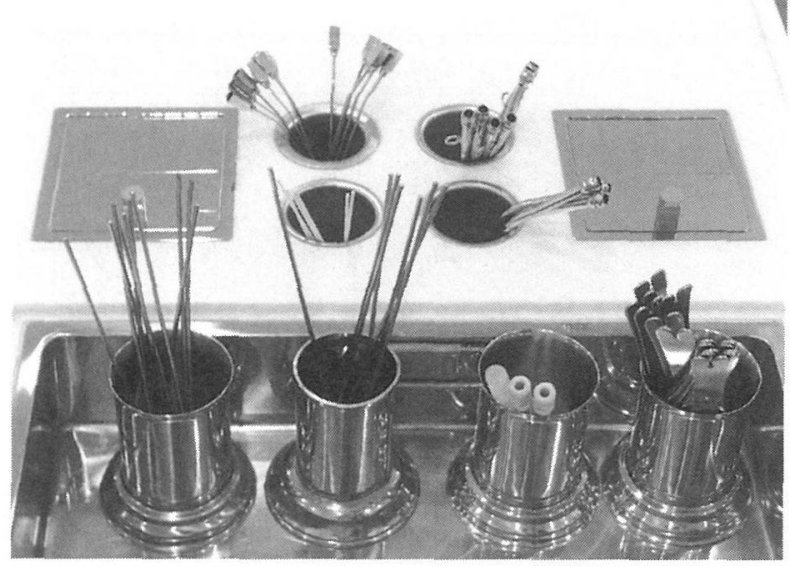

図 3 器具の配置

器具の先端部分に触れないように配置する.

吸引管，通気管などが含まれる。非金属製は喉頭鏡や上 咽頭鏡などの鏡を含むもの, ポリッツェル球のようにゴ ム製のもの，ネブライザー関係の器具や軟性内視鏡が含 まれる。

一般的に, 耳鼻咽喉科外来器具の消毒や滅菌は, 侕熱 性のものは洗浄 $\rightarrow$ 物理的消毒 $\rightarrow$ 乾燥 $(\rightarrow$ 高圧蒸気滅 菌), 非耐熱性のものは洗浄 $\rightarrow$ 化学的消毒 $\rightarrow$ すず $\rightarrow$ 乾燥の二通りの方法が行われている677).

(1) 洗浄

使用された耳鼻咽喉科器具は膿汁，血液や唾液などの 有機物が付着している。器具に有機物が付着したままで あるとその後の消毒や滅菌が不十分となる。特に，凹凸 や内腔のある耳鼻咽喉科器具の洗浄は醭素洗浄剤に浸漬 しただけでは不十分で，タンパク質が約 85\%残留したと 報告されている8)。現在，器具はできるだけ早期酒酵素 洗浄剤に浸漬した状態で超音波洗浄を行うこと，あるい は早期に流水による用手洗浄を行うことが望ましいと 考えられている ${ }^{8199}$. 用手洗浄では医療従事者の感染予防 のために，作業者はゴム手袋やマスクをつける必要があ $3^{9)}$.

（2）金属製器具の消毒と滅菌

頻回に使用する金属製のセミクリティカル器具は，使 用の度に煮沸消毒器による煮沸消毒や熱水消毒によって 経済的で安全な消毒が可能である，煮沸や熱水消毒の後 は乾燥機を用いて乾燥させ，使用する（図 4)。超音波洗 浄, 熱水消毒と乾燥の工程が自動的に行える卓上の消毒 器が発売されている（図 5)。いずれにしても洗浄 $\rightarrow$ 物

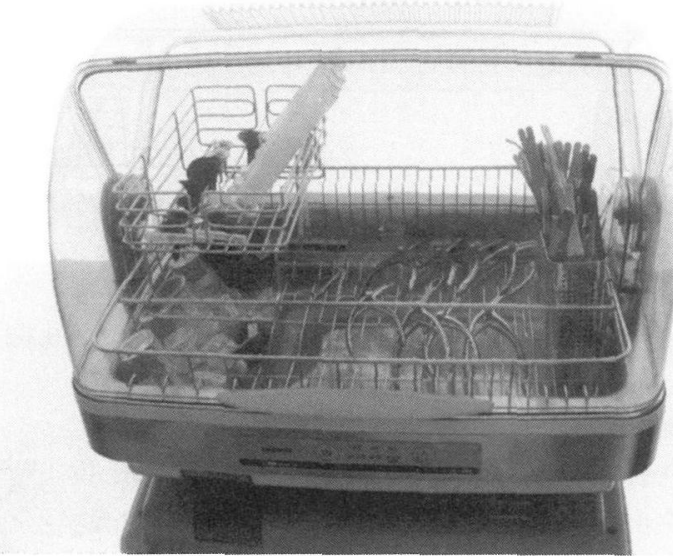

図 4 乾燥器による器具の乾燥 家庭用の食器乾燥器を用いて器具の乾燥を図る。

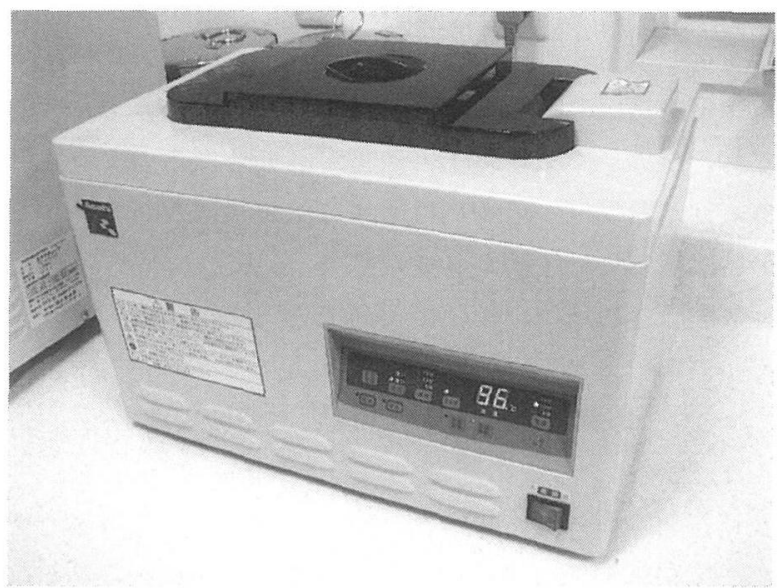

図 5 超音波洗浄, 熱水消毒と乾燥が組み合わされた卓上消毒器

理的消毒 $\rightarrow$ 乾燥の行程に約 1 時間の時間を要する.

さらに, 滅菌バッグに入れて高圧蒸気滅菌装置（オー トクレイブ）での滅菌が行われ，1〜3力月間保管してお くことができる。また，煮沸や熱水消毒を行った器具も 当日の最後には高圧蒸気滅菌装置（オートクレイブ）で の滅菌を行い，翌日の使用に備える。

本来，金属製器具に対しては高圧蒸気滅菌装置（オー トクレイブ）での滅菌が行われればその前に消毒は不要 である。しかし，滅菌の前段階として，器具に付着した 有機物の除去のための洗浄や乾燥は必須の作業であり, 作業者が感染する危険性がある，煮沸や熱水消毒を行っ た器具は素手で触っても感染の可能性はない。したがっ 
て，滅菌前には消毒が一般的に行われている.

（3）非金属製器具の消毒と滅菌

a. 耐熱性のもの

ゴム製のポリッツェル球は高圧蒸気滅菌が可能であ る. その他，非金属でも耐熱性のものは多いが，繰り返 しの高圧蒸気滅菌や物理的消毒で変形をきたすものがあ り注意が必要である.

\section{b. 非耐熱性のもの}

喉頭鏡や上咽頭鏡などの鏡を含むものは繰り返し煮沸 や高圧蒸気滅菌を行うと鏡面に晨りが生じる. そのため, 高水準の消毒薬（グルタラールやフタラール）に，決め られた濃度で, 決められた時間浸漬し, 滅菌水ですすぎ を行い，乾燥させて利用する．すすぎを十分行わないと 粘膜炎を起こすことが報告されている ${ }^{9)}$. また, 滅菌水 でなく水道水ですすぎを行った場合, 水道水にクリプト スポリジウム, 非定型抗酸菌やレジオネラが存在する可 能性があり, 最後にアルコールでのすすぎが薦められて いる ${ }^{1)}$. 水道水による耳洗浄によって非定型抗酸菌によ る中耳炎の報告がある ${ }^{10)}$.

ネブライザー関係の器具, 特に超音波ネブライザーで はマウスピース, 逆流防止弁, 吸気ホース, 薬液カップ などが消毒や滅菌の対象となる，このうち，マウスピー スは耐熱性とされている. 耳鼻咽喉科外来ではネブライ ザーを使用する頻度は高く, ブドウ糖非発酵グラム陰性 桿菌により器具が污染され, グラム陰性桿菌による院内 感染が報告されている1112).

マウスピースや逆流防止弁は患者ごと, 吸気ホースや 薬液カップは毎日消毒や滅菌が必要である。これらは洗 浄後に, 中水準の消毒薬（次亜塩素酸ナトリウム）に, 決められた濃度 $(0.02 \mathrm{~W} / \mathrm{V} \%)$ で，決められた時間（5 分以上）浸漬し, 乾燥して使用する. 吸気ホースは消毒 後の乾燥が十分行われれば感染源にはなりえないことが 報告されている ${ }^{13)}$ ，次亜塩素酸ナトリウムは金属腐食性 があるため金属製器具には用いられないが，低残留性で あるため口内に挿入する器具の消毒に汎用されている11. 中水準の消毒薬であるが, 芽胞にやや抵抗性がある以外 ウイルス, 結核菌, 真菌などほとんどの病原体を不活性 化あるいは殺滅する。

また，ネブライザーに使用する吸入液の管理を十分行 う必要がある.吸入液の長期間にわたる分割使用は避け, 当日に使い切ることが原則である ${ }^{14)}$. 希釈に用いる滅菌 精製水も污染される可能性があり, 同様の注意が必要で
ある。

その他，吸入液の計量に用いるディスポーザブルの注 射器は毎日交換する ${ }^{14)}$. 作用槽内の蒸留水も毎日交換し, 内部はアルコール消毒を行う.

c. 軟性内視鏡

耳鼻咽喉科外来での観察用の軟性内視鏡の使用頻度は 高く, いかに短時間で安全な消毒を行えるかが課題であ る. 近年は自動洗浄機が普及してきている. 1分間の流水 洗浄後に, 高水準の消毒液への浸漬, その後再び 2 分間 の流水洗浄を行う方法の有効性が報告されている ${ }^{15)}$. 一 般的には, 高水準の消毒薬として $2 \sim 3 \mathrm{~W} / \mathrm{V} \%$ のグルタ ラールヘの 10 分間の浸漬が推奨されているが,フタラー ルはより短い浸漬時間（5 分間）での消毒が可能である. 内視鏡に損傷部分があると消毒薬が残存しやすいと報告 されている16). 自然乾燥後に使用できるが，アルコール 綿やガーゼで軽く水滴を拭きとることでも使用できる.

吸引や生検鉗子のチャンネルがある内視鏡では，はじ めにチャンネル内をブラッシングして粘液などの分泌物 や血液を除く必要がある。 また，チャンネル内には高水 準の消毒薬を注入し, 滅菌精製水でのすすぎ，その後ア ルコールを注入して乾燥させる. 生検鉗子は予備洗浄と 超音波洗浄後に高圧蒸気滅菌が必要である ${ }^{11}$.

3. 耳鼻咽喉科外来のその他の設備や環境の消毒

（1）その他の設備の消毒

よく手にする外来手術用顕微鏡のハンドルや患者に触 れる可能性が高いユニットスプレーの先端部はアルコー ル綿などで清拭する ${ }^{6)}$. 綿棒立てなどの容器は毎日, 薬 瓶は週 1 回薬液を廃棄し, 高圧蒸気滅菌を行う6). 大きな リネン類は外注文による消毒の依頼となるが，血液や睡 液が付着したタオル類は次亜塩素酸ナトリウムを加えた 洗䍜を行う ${ }^{1)}$.

（2）外来環境の消毒

床はモップを次々と交換しながら清掃を行う。モップ の消毒は洗浄後, 中水準の消毒薬である次覀塩素酸ナト リウムに浸漬した後乾燥させる ${ }^{1}$. 待合室の椅子, 車椅 子，ドアノブや点滴台支柱などは低水準消毒薬である第 4 級アンモニウム塩などで清拭する1). 清拭作業中はゴム 手袋やマスクを着用する.

\section{おわりに}

耳鼻咽喉科外来の器具の消毒や滅菌に関してどうある べきか，あるいはどうすればより有効かについての議論 
は重要である. 本論説が一般耳鼻咽喉科診療所の開設や 診療充実の一助となれば幸いである。

本論説の発表に際し，ご助言いただいた長崎大学大学院医歯 薬学総合研究科病態制御学講座 高橋晴雄教授に深謝いたしま す.

\section{参考文献}

1）小林寛伊：1，感染症法とガイドライン，2，消毒・滅菌法 一基礎と実際一. 改訂 消毒と滅菌のガイドライン（小林 寛伊編). 1 ～134 頁, 一るす出版, 東京, 2004.

2) Spaulding $\mathrm{EH}:$ Chemical disinfection of medical and surgical materials. Disinfection, Sterilization and Preservation (ed by Lawrence CA and Block SS). pp 617 641, Lea \& Febiger, Philadelphia, 1991.

3) Garner JS and Favero MS : CDC guideline for handwashing and hospital environmental control. 1985. Infect Control 7 : $231 \sim 243,1986$.

4) Rutala WA : APIC guideline for selection and use of disinfectants. 1994, 1995, and 1996. Am J Infect Control $24: 313 \sim$ 342, 1996.

5）塙 力哉, 伊藤 尚, 竹中 洋: 耳鼻咽喉科における MRSA に対する消毒の効果. 日耳鼻感染誌 $16: 47 \sim 50,1998$.

6) 板橋隆嗣：外来診療器具の消毒. JOHNS $10: 1187 \sim 1192$, 1994.

7）齋藤彰治, 新川 郭, 飯田政弘：実地医家における耳鼻咽 喉科ユニット関係器材・ネブライザー関係器材の消毒. 日 耳鼻感染誌 $15 ： 122 \sim 128,1997$.
8）大庭みよ，今野久子，高橋ますみ，他：耳鼻科外来におけ る使用済み器具の一次処理方法の検討一醉素洗浄剤の蛋白 質除去効果の調査より一. 日本看護学会論文集 33 回看護総 合 $121 \sim 123,2002$.

9) 小林仁和, 宮国泰明, 涌谷忠雄: 殺菌消毒剤 (STERIHYDE) による腐食性咽喉頭炎. 耳鼻 $28 ： 1121 \sim 1125 ， 1982$.

10) Lowry PW and Jarvis WR : Use of tap water and disinfection practices in outpatient settings. A survey of otolaryngologists. Arch Otolaryngol Head Neck Surg 117 : 886 888, 1991.

11）岸本 厚, 酒井正喜, 森 淳, 他 : 外来, 病棟に抢ける 環境の污染状況. 日耳鼻感染誌 $14: 145 \sim 150,1996$.

12）勝井則明, 加藤信行, 浅田祥司, 他 :ネブライザーによる 院内感染とその対策. J Antibact Antifung Agents $26: 321 〜$ 326, 1998.

13）勝井則明，真鍋美智子：微生物污染の観点からみたネブラ イザーの蛇管扩よびエアフィルターの危險性についての評 価. 手術医学 23: $112 \sim 116,2002$.

14）尾家重治, 神谷晃：吸入療法に用いていた吸入液の細菌污 染. J Antibact Antifung Agents $21 ： 233 \sim 236,1993$.

15）細川 晃, 板橋隆同，太田智幸，他：鼻咽喉ファイバース コープ消毒器の新しい使用方法. 日耳鼻感染誌 $15: 117$ 121, 1997.

16）板橋隆嗣，中川利香，藤森正登：内視鏡消毒後の消毒剤の 残存. 耳鼻臨床 $87 ： 1573 \sim 1578 ， 1994$

別刷請求先 : 重野浩一郎

テ 852-8132 長崎市扇町1-21

重野耳鼻咽喉科 めまい・難聴クリニック 